\title{
PENGARUH MEDIA DART BOARD TERHADAP MINAT BELAJAR KIMIA SISWA PADA MATERI KOLOID DI KELAS XI SMA NEGERI 12 BANJARMASIN
}

\section{The Influence of Dart Board To Student's Learning Outcomes On Redox Material Class X In SMA Negeri 1 Alalak}

\author{
Novianti, Okviyoandra Akhyar, Mohan Taufiq Mashuri \\ Program Studi Pendidikan Kimia Fakultas Keguruan dan Ilmu Pendidikan \\ Universitas Islam Kalimantan Muhammad Arsyad Al Banjari, Banjarmasin \\ *e-mail: Nnovianti848@gmail.com
}

\begin{abstract}
Abstrak. Penelitian ini dilaksanakan di SMA Negeri 12 Banjarmasin dengan tujuan untuk mengetahui ada tidaknya pengaruh media dart board terhadap minat belajar kimia siswa pada materi koloid. Penelitian ini menggunakan penelitian kuantitatif jenis eksperimen semu dengan desain penelitian nonequivalent control group design. Populasi pada penelitian ini adalah seluruh siswa kelas XI IPA di SMA Negeri 12 Banjarmasin yang terdiri dari 3 kelas yaitu kelas XI IPA 1, XI IPA 2, dan XI IPA 3. Sampel dalam penelitian ini yaitu kelas XI IPA 1 sebagai kelompok eksperimen dan kelas XI IPA 2 sebagai kelompok kontrol. Instrumen yang digunakan untuk mengukur minat belajar siswa berupa angket. Berdasarkan hasil analisis data uji mann whitney $u$ dengan bantuan program SPSS 16.0 for windows diperoleh nilai sig sebesar $0,039<0,05$, maka $\mathrm{H}_{0}$ ditolak dan $\mathrm{H}_{\mathrm{a}}$ diterima, sehingga dapat disimpulkan bahwa ada pengaruh media dart board terhadap minat belajar kimia siswa pada materi koloid.
\end{abstract}

Kata Kunci: Dart board, minat belajar

Abstract. This research was carried at SMA Negeri 12 Banjarmasinwith the aim to find out whether or not there is a dart board against the influence of media interest in learning chemistry students on colloidal material. This research is quantitative research the type of quasi experiment with nonequivalent control group design. The population in this research were all students of class XI IPA in SMA Negeri 12 Banjarmasin consisting of 3 classes, namely class XI IPA I, XI IPA 2, and XI IPA 3. The sample in this research were class XI IPA 1 as the experiment class and class XI IPA 2 as the control class. Instrument used to measure students learning interest in the form of interest question form. Based on the result of the mann whitney $u$ test with the help of SPSS 16.0 for windows program obtained sig value of 0,039 < 0,05, then $H_{0}$ is rejected and $H_{a}$ is a accepted, so that it can be concluded that there is a media dart board against the interest in learning chemistry students on colloidal material.

Keywords: Dart board, interest to learn

\section{PENDAHULUAN}

Minat merupakan suatu rasa lebih suka dan rasa keterikatan pada suatu hal atau aktivitas, tanpa ada yang menyuruh (Slameto, 2003). Menurut To'at \& Hidayah (2017) minat menjadi sumber motivasi yang kuat dan menjadi penyebab partisipasi serta 
keaktifan siswa dalam kegiatan pembelajaran. Pendapat serupa dijelaskan oleh Adodo \& Gbore (2012), bahwa minat menjadi salah satu aspek terpenting dalam mendorong keberhasilan pembelajaran, karena akan memunculkan ingatan yang baik bagi siswa. Menurut Djamarah (2011) siswa yang kehilangan minat dalam belajar akan lebih mudah melupakan materi yang baru saja mereka pelajari. Oleh karena itu, menurut Haryanti \& Wiyarsi (2007) siswa dengan minta belajar yang baik akan menunjukkan aktivitas yang positif selama pembelajaran, sedangkan siswa yang cenderung pasif diindikasikan memiliki minat belajar yang rendah.

Pelajaran kimia merupakan ilmu yang mencari atas pertanyaan apa, mengapa, dan bagaimana gejala-gejala alam yang berkaitan dengan komposisi, struktur dan sifat, perubahan, dinamika, dan energitika zat (Mulyasa, 2011). Sebagian besar siswa tidak menyenangi pelajaran kimia. Mereka berpendapat bahwa pelajaran kimia adalah pelajaran yang sulit, kurang bermanfaat, membosankan, membahayakan dan menakutkan (Nazhifah dkk, tanpa tahun). Mereka yang kurang menyenangi pelajaran kimia cenderung memiliki persepsi negatif dan tidak tertarik dengan masalah-masalah yang menyangkut kimia. Dari persepsi dan rasa ketidaktertarikan tersebut, maka semangat dan kemauan untuk belajar kimia menjadi redup.

Guru sebagai tenaga pendidik maupun pengajar memiliki peranan yang penting dalam membangkitkan minat belajar siswa. Guru dituntut kreatif menciptakan kondisikondisi pembelajaran yang menyenangkan. Kondisi pembelajaran tersebut dapat diciptakan guru melalui media permainan. Permainan merupakan aktivitas yang dilakukan karena seseorang ingin mencapai suatu kesenangan atau kegembiraan serta kepuasan. Tujuan dilakukannya permainan adalah untuk menghindari atau menghilangkan kejenuhan, kebosanan, perasaan mengantuk siswa selama pembelajaran berlangsung dan menumbuhkan minat siswa. selain itu, penggunaan media permainan juga dapat melatihkan nilai afektif seperti rasa tanggung jawab, sportifitas, kejujuran dan rasa pantang menyerah (Listiani \& Prihatnani, 2018). Salah satu bentuk media permainan adalah dart board (Papan Panahan).

Dart board merupakan sebuah media permainan yang menggunakan papan panah, berisikan soal-soal yang nantinya harus dikerjakan oleh siswa dan diambil dengan cara melemparkan panah ke arah soal tersebut. Kelebihan dari media permainan ini adalah mampu meningkatkan aktivitas siswa, sehingga siswa lebih bersemangat mengerjakan soal yang diberikan oleh guru (Cahyani dkk, 2017).

Terdapat beberapa penelitian yang telah memanfaatkan media dart board dalam pembelajaran, contohnya penelitian yang dilakukan oleh Listiani \& Prihatnani (2018) yang mengembangkan dan memanfaatkan media dart board dalam pembelajaran matematika, Wulandari dkk (2018) menggunakan media dart board dalam pembelajaran kimia, Aquariza \& Saputri (2017) memanfaatkan media dart board dalam pembelajaran bahasa inggris, dan Susanti \& Sukanti (2016) menggunakan media dart board dalam pembelajaran akuntansi.

Berdasarkan uraian di atas, maka penelitian ini bertujuan untuk mengetahui pengaruh penggunaan media dart board terhadap minat belajar siswa pada materi kimia, khususnya sistem koloid. 


\section{METODE PENELITIAN}

Jenis penelitian ini adalah kuasi eksperimen dengan desain nonequivalent control group design. Desain penelitian Nonequevalent Control Group Design dapat dilihat pada Tabel 1 berikut.

Tabel 1. Desain Nonequivalent Control Group Design

\begin{tabular}{cccc}
\hline Kelas & Pre-test & Perlakuan & Post-test \\
\hline Eksperimen & $\mathrm{O}_{1}$ & $\mathrm{X}$ & $\mathrm{O}_{2}$ \\
Kontrol & $\mathrm{O}_{3}$ & - & $\mathrm{O}_{4}$
\end{tabular}

Sumber : Sugiyono (2015:116)

Keterangan :

$\mathrm{O}_{1} \quad=$ Pre-test kelas eksperimen

$\mathrm{O}_{2} \quad=$ Post-test kelas eksperimen

$\mathrm{O}_{3} \quad=$ Pre-test kelas kontrol

$\mathrm{O}_{4} \quad=$ Post-test kelas kontrol

$\mathrm{X} \quad=$ Perlakuan pembelajaran menggunakan media permainan kotak katik pada kelas eksperimen

Penelitian dilakukan di SMA Negeri 12 Banjarmasin. Populasi penelitian adalah seluruh siswa kelas XI yang terdiri dari 3 kelas dengan jumlah 72 siswa. Sampel penelitian adalah siswa kelas XI IPA 1 sebagai kelompok eksperimen dan kelas XI MIA 2 sebagai kelompok kontrol.

Data penelitian dikumpulkan menggunakan teknik nontes berupa angket minat belajar. Angket minat dibagikan sebelum dan sesudah pembelajaran. Data yang diperoleh melalui angket minat dianalisis menggunakan uji komparasional dengan bantuan SPSS 16 for windows.

\section{HASIL DAN PEMBAHASAN}

Berdasarkan data yang diperoleh, diketahui bahwa minat siswa di kelompok kontrol tidak jauh berbeda dengan siswa di kelompok eksperimen sebelum diberi perlakuan. Nilai rata-rata yang diperoleh tiap kelompok diberikan pada Gambar 1.

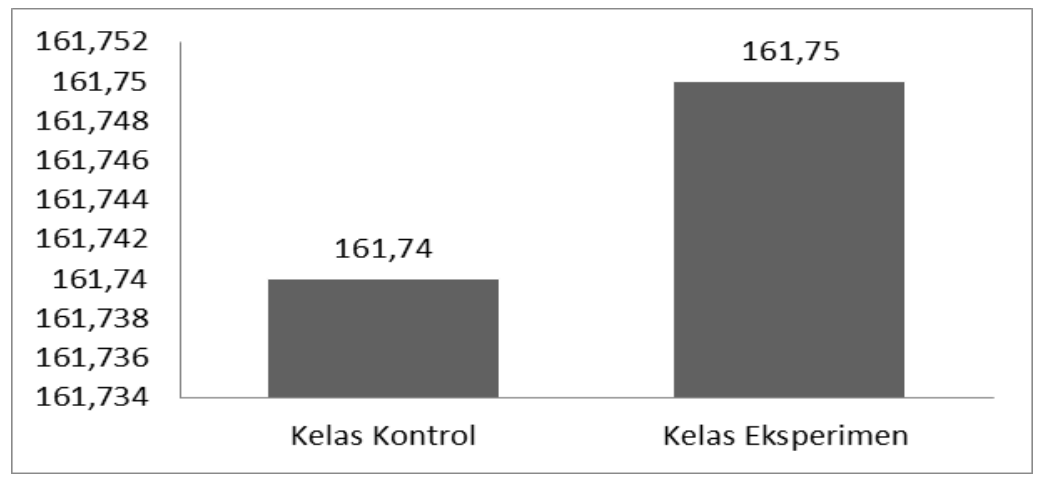

Gambar 1 Nilai rata-rata minat siswa sebelum perlakuan 
Dari Gambar 1 tersebut dapat dilihat bahwa terdapat perbedaan nilai rata-rata minat sebesar 0,01. Dengan demikian, dapat dikatakan bahwa minat siswa dikelompok kontrol dan eksperimen tidak berbeda, sehingga dapat diberi perlakuan. Berbeda dengan sebelum perlakuan, sesudah perlakuan minat siswa kelompok eksperimen tampak berbeda dengan minat siswa di kelompok kontrol. Siswa yang dibelajarkan dengan menggunakan dart board lebih semangat dan senang saat mengikuti proses pembelajaran. secara kuantitatif, minat siswa di kelompok kontrol dan eksperimen dapat dilihat pada Gambar 2 berikut.

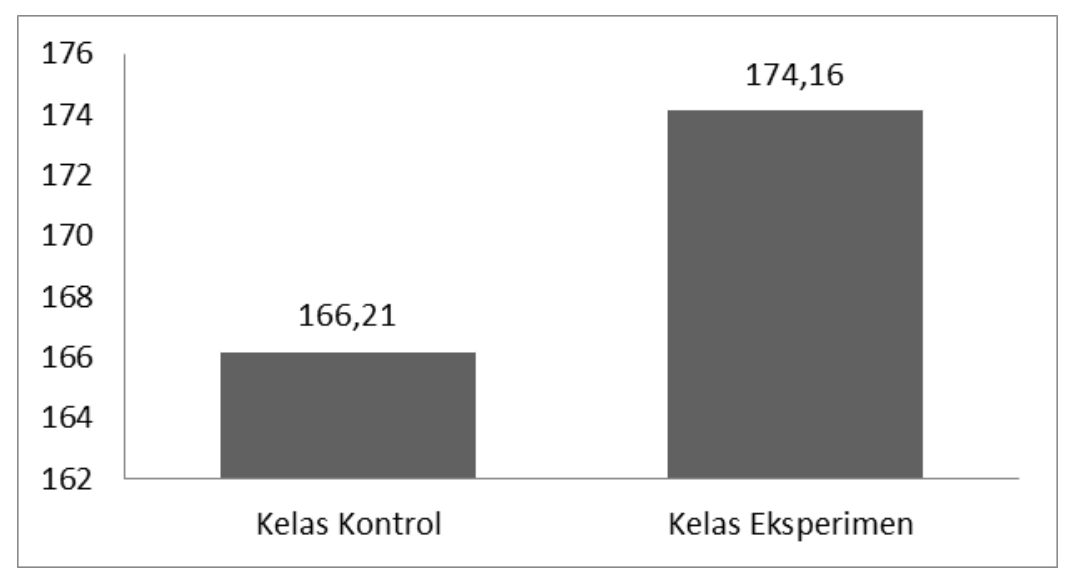

Gambar 2 nilai rata-rata minat siswa sesudah perlakuan

Dari Gambar 2 diketahui bahwa terdapat perbedaan nilai rata-rata minat siswa di kelompok kontrol dan eksperimen, dengan selisih yang cukup besar yaitu 7,95. Data tersebut kemudian diuji normalitas dan homogenitasnya. Berdasarkan hasil uji normalitas data menggunakan software SPSS 16.0 for windows didapatkan nilai sig 0,014 untuk kelompok kontrol dan nilai sig 0,005 untuk kelompok eksperimen, sehingga disimpulkan bahwa data tidak terdistribusi normal. Sedangkan hasil uji homogenitas menunjukkan bahwa data homogen, karena nilai sig $(0,579)>0,05$. Oleh karena data yang diperoleh tidak memenuhi syarat pengujian parametrik (data terdistribusi normal dan homogen), maka digunakan uji nonparametrik berupa mann whitney u-test. Dari hasil uji mann whitney $u$ menggunakan software SPSS 16.0 for windows didapatkan nilai sig 0,039. Dengan demikian, hasil pengujian menunjukkan bahwa terdapat perbedaan minat siswa yang dibelajarkan dengan dart board dan konvensional, dimana minat siswa yang dibelajarkan dengan dart board lebih tinggi dibanding siswa yang dibelajarkan dengan cara konvensional.

Permainan dart board dapat meningkatkan minat belajar siswa karena menghilangkan kejenuhan, kebosanan, dan persepsi negatif siswa mengenai kimia. Selain itu, melalui permainan dart board siswa dapat lebih tertarik dan tertantang dalam menyelesaikan latihan/soal-soal kimia, karena pemberian soal dikemas ke dalam kegiatan yang menarik dan tidak membosankan (listiani \& Prihatnani, 2018). Hal ini juga dipertegas oleh Djamah \& Zain (1996) yang menjelaskan bahwa latihan yang 
dilaksanakan secara berulang-ulang memberikan kesan monoton, sehingga diperlukan cara penyajian latihan soal yang menarik

\section{PENUTUP}

Kesimpulan dari penelitian ini adalah terdapat pengaruh media dart board terhadap minat belajar siswa pada materi koloid. Untuk peneliti selanjutnya sebaiknya meneliti dengan materi yang berbeda namun lebih banyak referensi lagi.

\section{DAFTAR RUJUKAN}

Adodo, S.O. \& Gbore, L. O.(2012). Prediction of Attitude and Interest of Science Students of Different Ability on Their Academic Performance in Basic Science. International Journal of Psychology and Counselling, 4(6): 68-72.

Aquariza, N. R. \& Saputri, T. (2017). PPM Pondok Pesantren Qomaruddin Bungah Gresik Pengenalan Dart Board sebagai Media Belajar Kosakata Bahasa Inggris. 1(2): 97-103.

Cahyani, N. A. P., Bariyyah, K. \& Latifah, L. (2017). Efektivitas Teknik Permainan Simulasi dengan Menggunakan Media Dart Board untuk Meningkatkan Motivasi Belajar Siswa Kelas VII C SMP Negeri 2 Tegal Siwalan Probolinggo. Jurnal Konseling Indonesia, 3(1):22-27.

Djamarah, S. B. \& Zain, A. (1996). Strategi Belajar Mengajar. Jakarta: Rineka Cipta.

Haryanti \& Wiyarsi, A. 2017. Analisis Minat Belajar Kimia SISwa Kelas XI SMK Negeri 1 Temon. Makalah disajikan pada seminar nasional kimia UNY. Universitas Negeri Yogyakarta.

Listiani, D \& Prihatnani. (2018). Pengembangan Media Pembelajaran Dart Board Math bagi Siswa Kelas VII SMP. Math Didactic: Jurnal Pendidikan Matematika, 4(1): 21-33.

Slamet. 2003. Belajar dan Faktor-faktor yang Mempengaruhinya. Jakarta: Rineka Cipta.

Sugiyono. 2015. Metode Penelitian Kuantitatif Kualitatif dan R\& D. Bandung: Alfabeta.

Susanti, P. M. \& Sukanti. 2016. Implementasi Model Pembelajaran Kooperatif Tipe Teams Games Tournament (TGT) dengan Media Dart Board untuk Meningkatkan Motivasi Belajar Akuntansi. Jurnal Kajian Pendidikan Akuntansi Indonesia, 8:1-17.

To'at, A. \& Hidayah, F. F. . Pengaruh Kompetensi Profesional Guru Kimia terhadap Minat Belajar Siswa Kelas XII IPA di MAN 1 Semarang. Makalah disajikan pada seminar nasional pendidikan, sains dan teknologi fakultas matematika dan ilmu pengetahuan alam. Universitas muhammadiyah semarang. 